\title{
Kuat Tekan Dan Kuat Tarik Belah Beton Polimer Termodifikasi Alami Amylum Serta Bahan Tambah Madu
}

\author{
Febri Satrio Nugroho; Putra Bintang Rizalditya; \\ Rr.M.I Rretno Susilorini dan Budi Santosa \\ e-mail: bosfebri@gmail.com, dan putrabintang03@gmail.com \\ Program Studi Teknik Sipil, Fakultas Teknik \\ Universitas Katolik Soegijapranata, Semarang
}

\begin{abstract}
The resesearch used amylum as a modified polymer and honey as its added ingredient. There were with 3 compositions with honey, 0\%; 0.03\%; and 0.3\%, and also 6 amylum compositions, $0.1 \% ; 0.2 \% ; 0.5 \% ; 1 \% ; 2 \%$; and 5\%. The number of specimens with $20 \mathrm{~cm}$ in length and 10 $\mathrm{cm}$ were 270 that were tested for compressive strength, and the number of specimens with 30 $\mathrm{cm}$ length and $15 \mathrm{~cm}$ in diameter were 90 that tested for splittingtensile strength. The results of this research met conslusions: (1). Optimum compressive strength achieved by specimen KT-M0,03-G with 0,03\% honey and 0,5\% amylum of cement weight; (2) Optimum splitting tensile strength achieved by specimen KTB-MO-A with 0,\% honey and 0,10\% amylum of cement weight;
\end{abstract}

Keyword: modified polymer concrete; compressive strength; splitting tensile strength; amylum; honey

\begin{abstract}
Abstrak
Penelitian ini menggunakan amylum sebagai polimer termodifikasi dan madu sebagai bahan tambahnya, dengan madu memiliki 3 kompoisi yaitu, $0 \% ; 0,03 \%$; dan 0,3\%, serta di setiap komposisi madu terdapat 6 kompoisisi amylum yaitu, 0,1\%;0,2\%; 0,5\%;1 \%; $2 \%$; dan $5 \%$. Jumlah benda uji berukuran panjang $20 \mathrm{~cm}$, dan diameter $10 \mathrm{~cm}$ adalah 270 benda uji untuk pengujian kuat tekan, dan jumlah benda uji berukuran panjang $30 \mathrm{~cm}$, dan diameter $15 \mathrm{~cm}$ total adalah 90 benda uji untuk uji kuat tarik belah. Hasil penelitian menunjukkan bahwa: (1)Pada pengujian kuat tekan beton, hasil optimum yang didapat adalah benda uji KT-M0,03-G dengan komposisi bahan tambah madu sebesar $0,03 \%$ dan amylum sebesar 0,5\% dari berat semen; (2)Pada pengujian kuat tarik belah beton, didapat hasil optimum pada benda uji KTB-M0-A dengan komposisi madu $0 \%$ dan amylum $0,10 \%$ dari berat semen.
\end{abstract}

Kata Kunci: beton polimer termodifikasi; kuat tekan; kuat tarik belah; amylum; madu 


\section{PENDAHULUAN}

Pengingkatan kualitas pengetahuan di sektor industri konstruksi, dibuktikan dengan munculnya gagasan baru dan penelitian untuk memberikan inovasi pada dunia konstruksi, salah satunya adalah beton.

Beton merupakan pilihan populer di sektor industri konstruksi untuk menunjang proses pembangunan sebuah konstruksi bangunan.

Inovasi dilakukan pada beton dengan menambahkan bahan tambah dalam campurannya, bahkan mencari solusi pengganti bahan penyusun dari beton tersebut tanpa mengurangi sifat dan karakteristik beton tersebut.

Dalam peneltian ini, digunakan polimer alami yaitu amylum, dan madu sebagai bahan tambah. Inovasi tersebut, diaharapkan mampu memberikan kekuatan yang lebih baik dari kekuatan rencana, dan tentunya pemilihan material yang baik juga menunjang tercapainya hasil yang maksimal.

Penelitian inimerupakan bagian dari penelitian payung yang berjudul "Strategi Adaptasi Masyarakat Pesisir Semarang dan Demak untuk Mitigasi Pengurangan Resiko Bencana Banjir dan Rob Akibat Perubahan Iklim" (Susilorini, et.al., 2017) yang memperoleh pendanaan dari INSINAS RPI (2017 - 2019), Kemristekdikti, Nomor Kontrak 35/INS/PPK/E/E4/ 2017-2019.

\section{TINJAUAN PUSTAKA}

\subsection{Beton}

Beton merupakan material komposit yang tersusun dari agregat halus, agregat kasar, dan bahan tambah jika diperlukan, yang mengalami proses kimiawi oleh air. (Mac Gregor, 1997).
Beton sendiri merupakan bagian penting dalam dunia konstruksi. Selain itu bahan penyusun beton haruslah merupakan pilihan yang terbaik untuk mengahasilkan kualiats beton yang terbaik.

\subsection{Semen}

Menurut ASTM C-150, 1985, semen Portland didefinisikan sebagai semen hidrolik yang dihasilkan dengan cara menggiling klinker yang terdiri dari dari silikat - silikat kalsium yang umumnya mengandung satu atau lebih bentuk kalsium sulfat sebagai bahan tambahan yang digiling bersama sama dengan bahan utamanya.Semen merupakan komponen tama beton, yaitu sebagai pengikat anatar bahan penyusun lainnya.

\subsection{Air}

Pada proses produksi beton, air berfungsi memunculkan reaksi kimia yang dihasilkan semenuntuk memberikan reaksi kepada agregat. Kandungan dan proporsi air yang digunakan juga diperhatikan, apabila kekurangan air akan menghambat proses reaksi kimia dari semen dan kelebihan air akan menyebabkan beton lemah terhadap proses hidrasi.

\subsection{Agregat}

Agregat merupakan bahan penyusun dalam proses produksi beton. Agregat sendiri merupakan sekumpulan batir batu pecah, kerikil, pasir, atau mineral lainnya yang merupakan hasil disintegrasi oleh alah atau penghancuran oleh alat penghancur.Agregat adalah salah satu faktor penentu kemampuan beton. Material yang dipilih pun harus memiliki sarat yang dibutuhkan untuk mencapai kekuatan yang direncanakan. 


\subsection{Beton Polimer}

Beton polimer merupakan beton yang bahan penyusunnya adalah polimer alami (bukan sebagai bahan tambah), bisa menggantikan sepenuhnya atau menggantikan sebagian (termodifikasi).Polimer yang digunakan adalah polimer alami amylum yang sering disebut pati.

\subsection{Bahan Tambah Beton}

Bahan tambahan beton merupakan suatu zat yang ditambahkan sebelum, saat atau sesudah porses produksi beton. Berguna untuk mempengaruhi karakter beton untuk memenuhi kebutuhan selama di lapangan.

Bahan tambah yang digunakan adalah madu. Madu menurut SNI 013545-2004, adalah cairan yang dihasilkan oleh lebah yang berasal dari berbagai sumber nectar. Madu berfungsi sebagai retarder, pengikat anatara semen dan polimer alami itu sendiri.

\subsection{Kuat Tekan}

Kuat tekan merupakan salah satu sifat mekanis beton,yaitu kemampuan beton menerima gaya tekan persatuan luas.Nilai kuat tekan diperoleh dari benda uji berukuran diameter $100 \mathrm{~mm}$ dan tinggi 200 $\mathrm{mm}$.

$f_{c}{ }^{\prime}=\frac{P}{A}$

Dimana:

$$
\begin{array}{ll}
f^{\prime} c^{\prime} & =\text { kuat tekan }(\mathrm{MPa}) \\
\mathrm{P} & =\text { beban tekan }(\mathrm{N}) \\
\mathrm{A} & =\text { luas penampang }\left(\mathrm{mm}^{2}\right)
\end{array}
$$

\subsection{Kuat Tarik belah}

Kuat tarik belah merupakan nilai kuat tarik dari benda uji berbentuk silinder yang melalui proses pembebanan dengan benda uji diletakkan sejajar mendatar di meja uji dengan alat uji kuat tekan.

Benda uji yang digunakan berbentuk silinder dengan ukuran diameter $150 \mathrm{~mm}$ dan tinggi 300 mm.

$$
f_{t}{ }^{\prime}=\frac{2 P}{\pi h t}
$$

Dimana:

$\mathrm{f}^{\prime} \mathrm{t}=$ kuat tarik belah beton pada umur 28 hari $(\mathrm{N} / \mathrm{mm} 2)$ $\mathrm{P}=$ beban maksimum $(\mathrm{N})$ $\mathrm{h}=$ tinggi silinder beton $(\mathrm{mm})$ $\mathrm{t}=$ diameter silinder beton (mm) 


\section{METODEPENELITIAN}

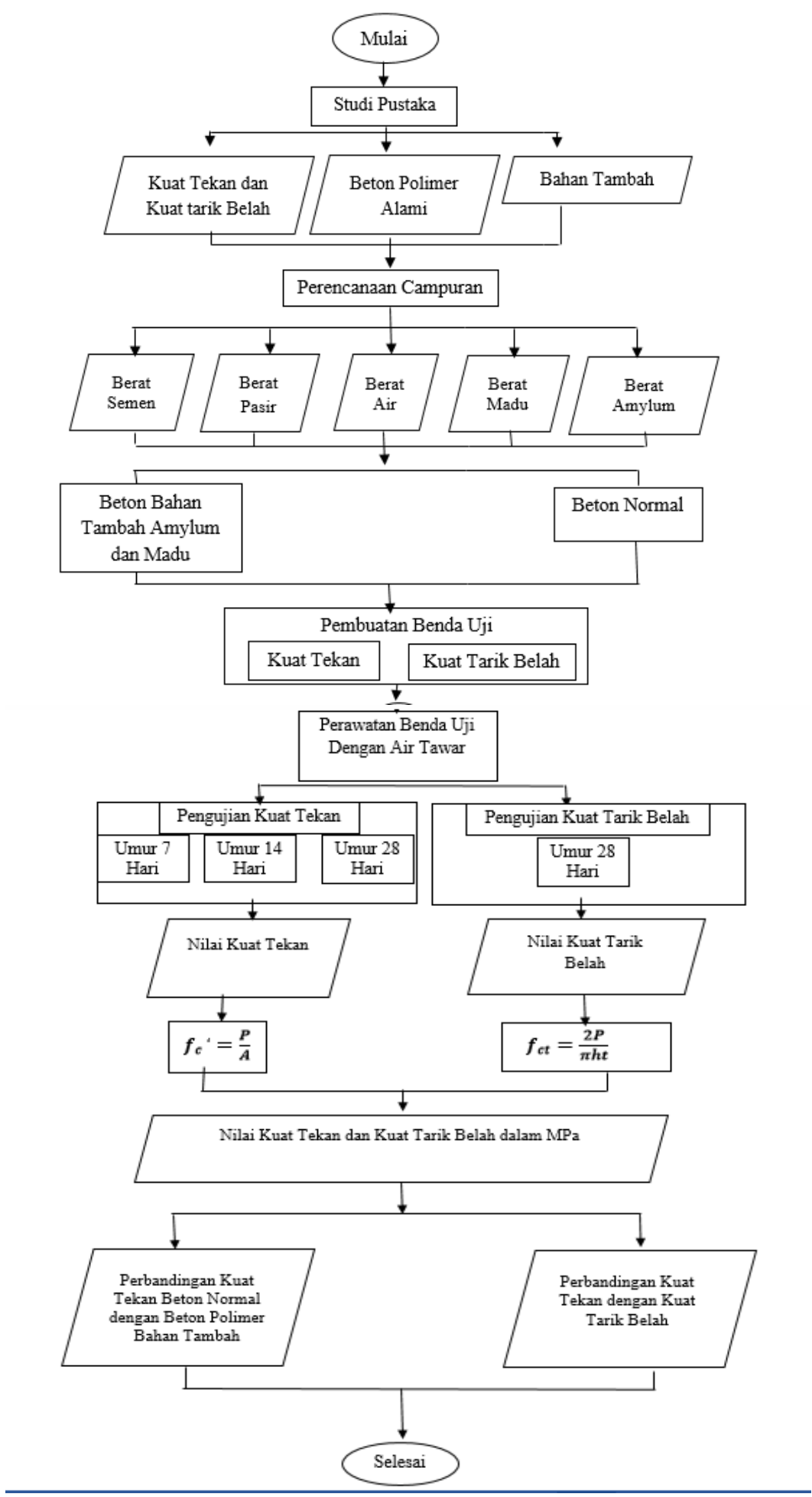

Gambar 3.1 Diagram Alir Penelitian 


\subsection{Jalannya Penelitian}

Penelitian dimulai dengan melakukan pengumpulan data dari penelitian yang pernah ada sebelumnya tentang pengaruh madu terhadap kuat tarik dan kuat tekan beton. Inovasi muncul dalam penelitian ini dengan menambah amylum. Tahap selanjutnya yaitu merencanakan benda uji silinder dengan mempersiapkan bahan- bahan yang dibutuhkan seperti semen, agregat halus, agregat kasar, air, amylum, serta madu.

Agar mendapat hasil beton yang maksimal perlu adanya pengujian bahan terlebih dahulu. Beberapa pengujian diantaranya pengujian kadar air, kadar lumpur, dan kandungan zat organis pada agregat halus.

Selanjutnya dilakukan pembuatan benda uji beton polimer termodifikasi alami amylum serta bahan tambah madu. Pada umur 1 hari, benda uji dilepas dari silinder dan dilakukan perawatan dengan cara direndam di dalam air (curing) selama 28 hari.

Setelah umur beton 28 hari, benda uji diangkat lalu dikeringkan dengan cara di angin- angin lalu dilakukan pengujian. Selanjutnya dilakukan pengujian kuat tekan dan kuat tarik pada beton lalu hasil yang muncul dicatat. Dari hasil pengujan kuat tarik dan kuat tekan benda uji beton, kemudian dilakukan analisa dan pembahasan.

\subsection{Perencanaan Beton}

Tabel dibawah ini adalah tabel komposisi beton. Berikut kandungan bahan tambah dan jumlah benda uji yang dilakukan dalam penelitian ini:
Tabel 3.1 Desain Percobaan Beton

\begin{tabular}{|c|c|c|c|c|}
\hline Kode Benda Uj & $\begin{array}{c}\text { Madu } \\
(\% \text { Berat Semen })\end{array}$ & $\begin{array}{c}\text { Amylum } \\
(\% \text { Berat Semen })\end{array}$ & \begin{tabular}{|c|} 
Jumlah Benda Uji \\
Utk Kuat Tekan
\end{tabular} & \begin{tabular}{|c} 
Jumlah Benda Uji \\
Utk Kuat Tarik
\end{tabular} \\
\hline KT-B-0-A & \multirow{6}{*}{0} & 0.1 & 15 & 5 \\
\hline KT-B-0-B & & 0.2 & 15 & 5 \\
\hline KT-B-0-C & & 0.5 & 15 & 5 \\
\hline KT-B-0-D & & 1 & 15 & 5 \\
\hline KT-B-0-E & & 2 & 15 & 5 \\
\hline KT-B-0-F & & 5 & 15 & 5 \\
\hline KT-B-0-G & \multirow{6}{*}{0.03} & 0.1 & 15 & 5 \\
\hline KT-B-0-H & & 0.2 & 15 & 5 \\
\hline KT-B-0-I & & 0.5 & 15 & 5 \\
\hline KT-B-0-J & & 1 & 15 & 5 \\
\hline KT-B-0-K & & 2 & 15 & 5 \\
\hline KT-B-0-L & & 5 & 15 & 5 \\
\hline KT-B-0-M & \multirow{6}{*}{0.3} & 0.1 & 15 & 5 \\
\hline KT-B-0-N & & 0.2 & 15 & 5 \\
\hline KT-B-0-0 & & 0.5 & 15 & 5 \\
\hline KT-B-0-P & & 1 & 15 & 5 \\
\hline KT-B-0-Q & & 2 & 15 & 5 \\
\hline KT-B-0-R & & 5 & 15 & 5 \\
\hline \multicolumn{3}{|c|}{ TOTAL BENDA UJI } & 270 & 90 \\
\hline
\end{tabular}

\subsection{Benda Uji Percobaan}

Benda uji yang dibuat berbentuk silinder beton untuk uji kuat tarik dengan dimensi diameter $15 \mathrm{~cm}$, tinggi $30 \mathrm{~cm}$, dan untuk uji kuat tekan memiliki dimensi diameter $10 \mathrm{~cm}$, dan tinggi $20 \mathrm{~cm}$ sesuai SNI 03-4810-1998. Kuat tekan rencana sebesar $30 \mathrm{MPa}$.

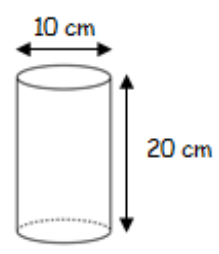

Gambar 3.2 Benda Uji Kuat Tekan Beton $(\mathrm{D}=10 \mathrm{~cm}, \mathrm{~T}=20 \mathrm{~cm})$

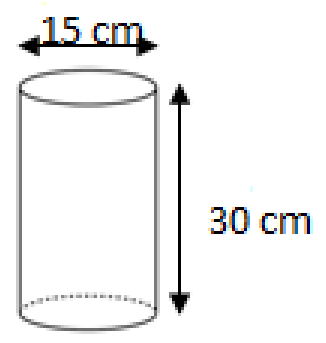

Gambar 3.3 Benda Uji Kuat Tarik Belah Beton $(D=15 \mathrm{~cm}, \mathrm{~T}=30 \mathrm{~cm})$ 


\subsection{Perawatan Benda Uji}

Perawatan benda uji baik dimensi 10 $\mathrm{cm} \times 20 \mathrm{~cm}$ maupun dimensi $15 \mathrm{~cm} \times 30$ cm dilakukan dengan cara direndam di genangan air atau Curing. Curing dilakukan setelah beton mencapai final setting, artinya beton sudah mengeras. Perawatan ini dilakukan supaya tidak ada gangguan pada saat beton mengalami proses hidrasi. Perawatan pada beton bertujuan untuk mendapatkan kuat tekan beton yang maksimal. Proses curing dilakukan hingga umur beton mencapai 28 hari.

\subsection{Tata Cara Pengujian 3.5.1Tata Cara Pengujian Kuat Tekan}

Pengujian beton dilaksanakan setelah proses curing selesai atau pada saat beton mencapai umur 28 hari. Pengujian mengacu pada ASTM C39 dengan menggunakan alat CTM (Compression Testing Machine) berkpasitas $250 \mathrm{KN}$. Cara pengujian dengan memberi beban pada benda uji. Benda uji diletakkan di tengah tumpuan penampang beton. Tuas yang ada pada mesin digerakkan secara manual agar mesin dapat bekerja dan dilakukan secara berulang hingga benda uji hancur. Catat hasil pengetesan yang ditunukkan oleh jarum penunjuk yang ada di mesin CTM.

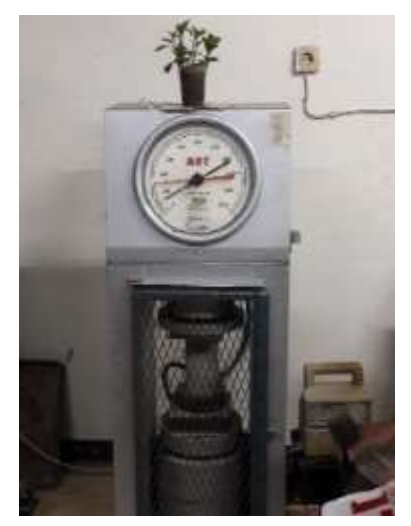

Gambar 3.4Compression Machine CO-325.4

\subsubsection{Tata Cara Pengujian Kuat Tarik}

Proses pengujian kuat tarik dengan cara meletakkan silinder secara mendatar diatas pelat dan ditekan pada bagian atas silinder secara merata. Pengujian silinder menggunakan alat bantu berupa papan kayu yang diletakkan dibagian atas dan bawah silinder. Setelah terpasang, proses pengujian dilakukan dengan cara menekan tuas yang ada pada alat CTM secara manual hingga benda uji retak dan kemudian hancur. Lalu catat hasil yang ditunjukkan oleh jarum yang ada pada mesin CTM.

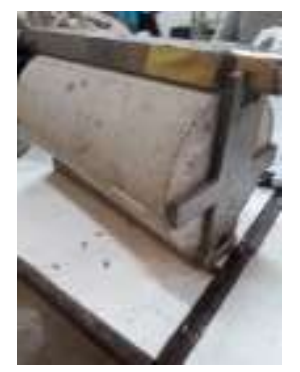

Gambar 3.5 Posisi Benda Uji Kuat Tarik Belah Saat Pengetesan

\section{HASIL DAN PEMBAHASAN}

\subsection{PENGUJIAN BAHAN}

\subsubsection{PENGUJIAN AGREGAT KASAR}

Berikut merupakan hasil pengujian agregat kasar:

1. Penyerapan air dan Spesific Gravity dari hasil uji bahan agregat halus, diperoleh hasil:
a. Apparent Specific Gravity : :4,4
b. Bulk Specific Gravity kondisi kering: 3,5
c. Bulk Specific Gravity kondisi SSD : 3,9
d. $\%$ penyerapan air $\quad: 5,65$ $\%$ 


\subsubsection{PENGUJIAN AGREGAT HALUS}

Berikut merupakan hasil pengujian agregat kasar:

1. Kadar lumpur, dengan hasil $3,84 \%$

2. Penyerapan air dan Spesific Gravity dari hasil uji bahan agregat halus, diperoleh hasil:

a. Apparent Specific Gravity : :3,84

b. Bulk Specific Gravity kondisi kering: 2,68

c. Bulk Specific Gravity kondisi SSD: 2,78

d. \% penyerapan air $\quad: 3,76 \%$

\subsubsection{PENGUJIAN AGREGAT HALUS}

Hasil dari pengujian madu disajikan Tabel 4.2 sebagai berikut:

Tabel 4.2 Hasil Pengujian

Laboratorium Madu

\begin{tabular}{|c|c|c|c|c|c|}
\hline No & Nama Sampel & Parameter & Nilai & Satuan & Metode \\
\hline \multirow{4}{*}{1} & \multirow{3}{*}{1} & Frukutosa & 586 & & \multirow{2}{*}{ HPLC } \\
\cline { 3 - 4 } & \multirow{3}{*}{ Madu } & Glukosa & Negatif & grL & HPL \\
\cline { 3 - 4 } & & Sukrosa & Negatif & & \\
\cline { 3 - 4 } & & Kadar Air & $16,150 \pm 0,263$ & $\%$ Berat & SNI 01 2891 1992 \\
\hline
\end{tabular}

\subsubsection{PENGUJIAN AGREGAT HALUS}

Hasil dari pengujian amylumdisajikan

Tabel 4.3. sebagai berikut:

Tabel 4.3 Hasil Pengujian

Laboratorium Amylum

\begin{tabular}{|c|c|c|c|c|c|c|c|}
\hline \multirow{2}{*}{ No } & \multirow{2}{*}{ Kode } & Air & Abu & Lemak & Protein & Karbohidrat & Lignin \\
\cline { 3 - 8 } & $\%$ & $\%$ & $\%$ & $\%$ & $\%$ & $\%$ \\
\hline 1 & \multirow{2}{*}{ Tepung Beras } & 11,875 & 0,424 & 0,652 & 5,888 & 81,160 & 11,293 \\
\hline
\end{tabular}

\subsection{PERENCANAAN CAMPURAN 4.2.1 PERENCANAAN CAMPURAN BETON}

Adapun ketentuan yang ditentukan dalam perencanaan campuran adalah sebagai berikut:

1. Kuat tekan beton : $30 \mathrm{MPa}$,
2. Nilai tambah (M): 5 Mpa, kuat tekan rencana rerata sebesar $35 \mathrm{MPa}$ untuk maksimal dan $25 \mathrm{Mpa}$ untuk minimum,

3. Jenis agregat halus : Semen Portland tipe I (PPC),

4. Jenis agregat kasar: Pasir Muntilan,

5. Jenis semen: Batu Pecah,

6. Ukuran maks. Kerikil : $20 \mathrm{~mm}$,

7. Nilai slump $: 10 \mathrm{~cm} \pm 2 \mathrm{~cm}$,

Dari hasil pengujian yang telah dilakukan, dihasilkan perhitungan kebutuhan untuk campuran beton setiap 1 $\mathrm{m}^{3}$ beton sebagai berikut:
1. Air
: 225 liter
2. Semen
: $500 \mathrm{~kg}$
3. Pasir
: $951 \mathrm{~kg} / \mathrm{m}^{3}$
4. Kerikil
: $1424 \mathrm{~kg} / \mathrm{m}^{3}$

Sehingga didapat perbandingan antara berat kerikil : pasir : semen : air yaitu: 2,85 $: 1,91: 1: 0,45$.

\subsection{HASIL PENGUJIAN DAN PEMBAHASAN}

Dari 3 buah benda uji dari masingmasing rincian tersebut dilakukan uji tekan dan dihitung rerata dari hasil pengujian tersebut. Hasil pengujian kuat tekan rerata untuk beton normal, sebagai berikut:

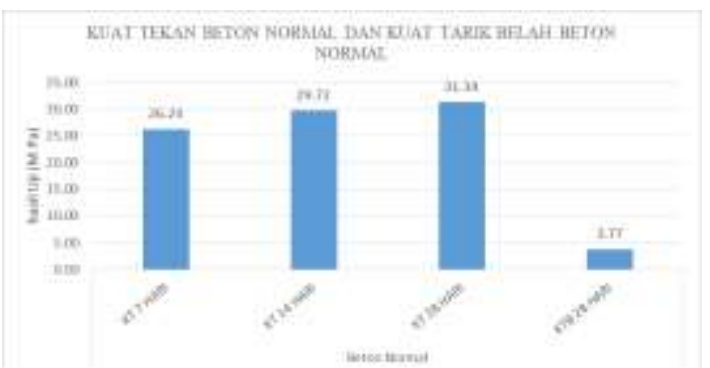

Gambar 4.1 Kuat Tekan dan Kuat Tarik Belah Normal Rerata Beton

Gambar 4.1 merupakan beton normal tanpa zat tambahan amylum dan madu. Hasil pengujian pada umur ke 28 hari memiliki kekuatan rerata tertinggi yaitu sebesar 31,34 MPa, sedangkan untuk umur 7 hari memiliki kekuatan rerata terendah sebesar 26,24 untuk kuat tekan beton 
normal. Dan untuk kuat tarik belah sebesar 3,77 MPa.

\subsubsection{Perbandingan Kuat Tekan Rerata Beton Normal dan Beton Polimer Termodifikasi Alami Amylum Serta Bahan Tambah Madu Pada Umur 7 Hari}

Berikut perbandingan kuat tekan beton normal dan beton yang telah termodifikasi madu dan amylum umur 7 Hari:

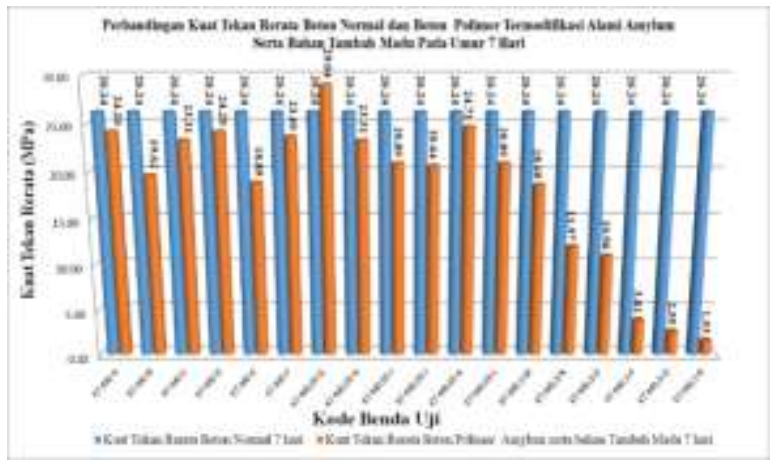

Gambar 4.2 Perbandingan Kuat Tekan Rerata Beton Normal dan Beton Polimer Umur 7 Hari

Benda uji dengan kode KT-M0,3-R dengan komposisi polimer alami amylum (5\% dari berat semen) dan bahan tambah madu (0,3\% dari semen). Pengujian pada umur 7 hari, menunjukkan bahwa benda uji dengan kode KT-M0,3-R memiliki nilai kuat tekan sebesar 1,53 MPa. Sedangkan untuk nilai kuat tekan rerata beton normal sebesar 26,24 MPa. Sehingga, dapat disimpulkan bahwa benda uji dengan kode KT-M0,3-R memiliki nilai kuat tekan rerata lebih kecil dari nilai kuat tekan rerata beton normal pada umur 7 hari.

Benda uji dengan kode KT-M0,03-G dengan komposisi polimer alami amylum ( $0,1 \%$ dari berat semen) dan bahan tambah madu $(0,03 \%$ dari semen). Pengujian pada umur 7 hari, menunjukkan bahwa benda uji dengan kode KT-M0,03-G memiliki nilai kuat tekan sebesar 29,04 MPa. Sedangkan untuk nilai kuat tekan rerata beton normal sebesar 26,24 MPa. Sehingga, dapat disimpulkan bahwa benda uji dengan kode
KT-M0,03-G memiliki nilai kuat tekan rerata lebih besar dari nilai kuat tekan rerata beton normal pada umur 7 hari.

\subsubsection{Perbandingan Kuat Tekan Rerata Beton Normal dan Beton Polimer Termodifikasi Alami Amylum Serta Bahan Tambah Madu Pada Umur 14 Hari}

Berikut perbandingan kuat tekan beton normal dan beton yang telah termodifikasi madu dan amylum umur 14 Hari:

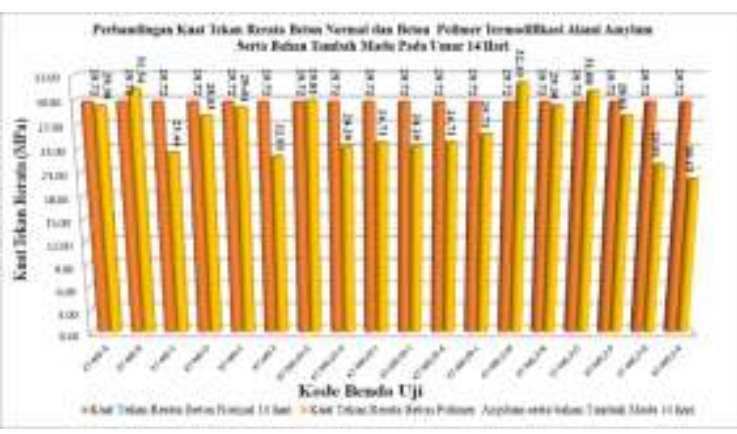

Gambar 4.3Perbandingan Kuat Tekan Rerata Beton Normal dan Beton Polimer Umur 14 Hari

Benda uji dengan kode KT-M0-E dengan komposisi polimer alami amylum (2\% dari berat semen) dan bahan tambah madu ( $0 \%$ dari semen). Pengujian pada umur 14 hari, menunjukkan bahwa benda uji dengan kode KT-M0-E memiliki nilai kuat tekan sebesar 19,04 MPa. Sedangkan untuk nilai kuat tekan rerata beton normal sebesar 29,72 MPa. Sehingga, dapat disimpulkan bahwa benda uji dengan kode KT-M0-E memiliki nilai kuat tekan rerata lebih kecil dari nilai kuat tekan rerata beton normal pada umur 14 hari.

Benda uji dengan kode KT-M0,3-O dengan komposisi polimer alami amylum (0,5\% dari berat semen) dan bahan tambah madu (0,3\% dari semen). Pengujian pada umur 14 hari, menunjukkan bahwa benda uji dengan kode KT-M0,3-O memiliki nilai kuat tekan sebesar 31,08 MPa. Sedangkan untuk nilai kuat tekan rerata beton normal sebesar 29,72 MPa. Sehingga, dapat disimpulkan bahwa benda uji dengan kode 
KT-M0,3-O memiliki nilai kuat tekan rerata lebih besar dari nilai kuat tekan rerata beton normal pada umur 14 hari.

\subsubsection{Perbandingan Kuat Tekan Rerata Beton Normal dan Beton Polimer Termodifikasi Alami Amylum Serta Bahan Tambah Madu Pada Umur 28 Hari}

Berikut perbandingan kuat tekan beton normal dan beton yang telah termodifikasi madu dan amylum umur 28 Hari:

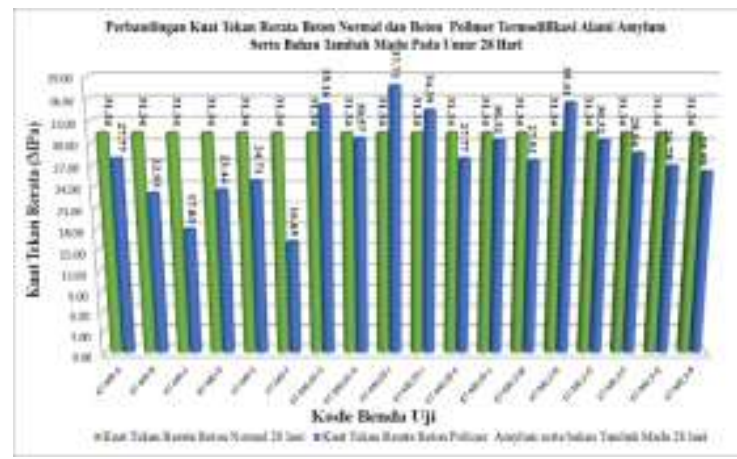

Gambar 4.3Perbandingan Kuat Tekan Rerata Beton Normal dan Beton Polimer Umur 28 Hari

Benda uji dengan kode KT-M0-F dengan komposisi polimer alami amylum (5\% dari berat semen) dan bahan tambah madu (0\% dari semen). Pengujian pada umur 28 hari, menunjukkan bahwa benda uji dengan kode KT-M0-F memiliki nilai kuat tekan sebesar 16,05 MPa. Sedangkan untuk nilai kuat tekan rerata beton normal sebesar 31,34 $\mathrm{MPa}$. Sehingga, dapat disimpulkan bahwa benda uji dengan kode KT-M0-F memiliki nilai kuat tekan rerata lebih kecil dari nilai kuat tekan rerata beton normal pada umur 28 hari.

Benda uji dengan kode KT-M0,03-I dengan komposisi polimer alami amylum (0,5\% dari berat semen) dan bahan tambah madu $(0,03 \%$ dari semen). Pengujian pada umur 28 hari, menunjukkan bahwa benda uji dengan kode KT-M0,03-I memiliki nilai kuat tekan sebesar 37,71 MPa. Sedangkan untuk nilai kuat tekan rerata beton normal sebesar 31,34 MPa. Sehingga, dapat disimpulkan bahwa benda uji dengan kode KT-M0,03-I memiliki nilai kuat tekan rerata lebih besar dari nilai kuat tekan rerata beton normal pada umur 28 hari.

\subsubsection{Perbandingan Kuat Tarik Belah Rerata Beton Normal dan Beton Polimer Termodifikasi Alami Amylum Serta Bahan Tambah Madu Pada Umur 28 Hari}

Berikut perbandingan kuat tarik belah beton normal dan beton yang telah termodifikasi madu dan amylum umur 7 Hari:

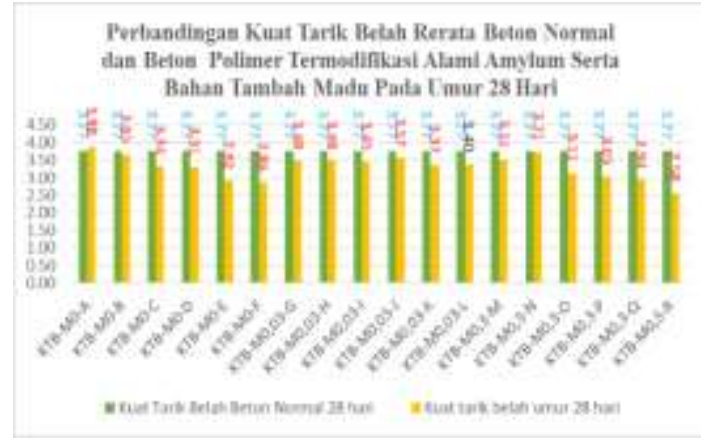

Gambar 4.4Perbandingan Kuat Tarik Belah Rerata Beton Normal dan Kuat Tarik Belah Beton Polimer

Termodifikasi Alami Amylum serta Bahan Tambah Madu pada Umur 28 Hari

Benda uji dengan kode KT-M0-A dengan komposisi polimer alami amylum $(0,1 \%$ dari berat semen $)$ dan bahan tambah madu (0\% dari semen). Pengujian pada umur 28 hari, menunjukkan bahwa benda uji dengan kode KT-M0-A memiliki nilai kuat tarik belah sebesar 3,88 MPa. Sedangkan untuk nilai kuat tarik belah rerata beton normal sebesar 3,77 $\mathrm{MPa}$. Sehingga, dapat disimpulkan bahwa benda uji dengan kode KT-M0-A memiliki nilai kuat tarik belah rerata lebih besar dari nilai kuat tarik belah rerata beton normal pada umur 28 hari.

Benda uji dengan kode KT-M0-R dengan komposisi polimer alami amylum (5\% dari berat semen) dan bahan tambah madu $(0,3 \%$ dari semen). Pengujian pada umur 28 hari, menunjukkan bahwa benda 
uji dengan kode KT-M0-R memiliki nilai kuat tarik belah sebesar 2,58 $\mathrm{MPa}$. Sedangkan untuk nilai kuat tarik belah rerata beton normal sebesar 3,77 $\mathrm{MPa}$. Sehingga, dapat disimpulkan bahwa benda uji dengan kode KT-M0-R memiliki nilai kuat tarik belah rerata lebih kecil dari nilai kuat tarik belah rerata beton normal pada umur 28 hari.

\subsubsection{Perbandingan Kuat Tekan Rerata Beton Polimer Termodifikasi Alami Amylum Serta Bahan Tambah Madu 0\% Pada Umur 7, 14, 28 Hari}

Berikut perbandingan kuat tekan beton normal dan beton yang telah termodifikasi madu $0 \%$ pada umur $7,14,28$ hari:

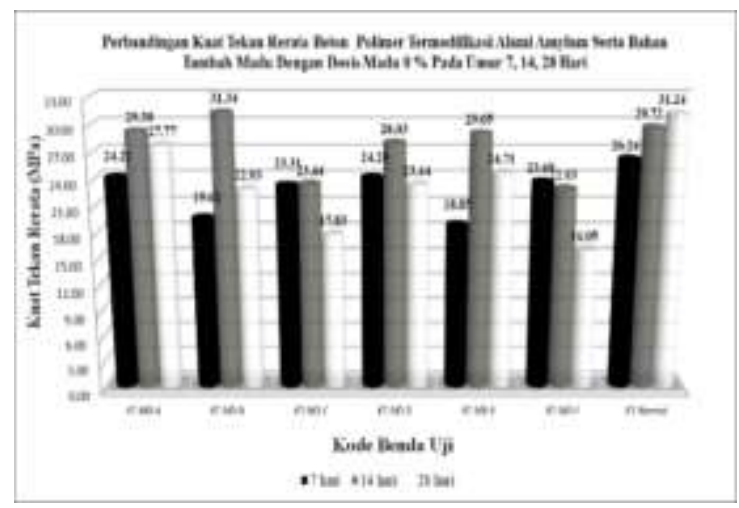

Gambar 4.5Perbandingan Kuat Tekan Rerata Beton Normal dan Beton Polimer Termodifikasi Alami Amylum serta Bahan

Tambah Madu dengan dosis Madu 0\% pada Umur 7, 14, dan 28 Hari

Dari gambar 4.5, dapat diketahui bahwa hasil dari pengujian kuat tekan beton polimer termodifikasi alami amylum serta bahan tambah madu paling optimum terdapat pada benda uji dengan kode KTM0-A. Kode uji KT-M0-A memiliki grafik kenaikan yang stabil dan mengalami penurunan kekuatan yang tidak terlalu signifikan dibanding kode benda uji lainnya.

\subsubsection{Perbandingan Kuat Tekan Rerata Beton Polimer Termodifikasi Alami Amylum Serta Bahan Tambah Madu Dengan Dosis Madu 0,03\% Pada Umur 7, 14, 28 Hari}

Berikut perbandingan kuat tekan beton normal dan beton yang telah termodifikasi madu $\mathbf{0 , 0 3} \%$ pada umur $7,14,28$ hari:

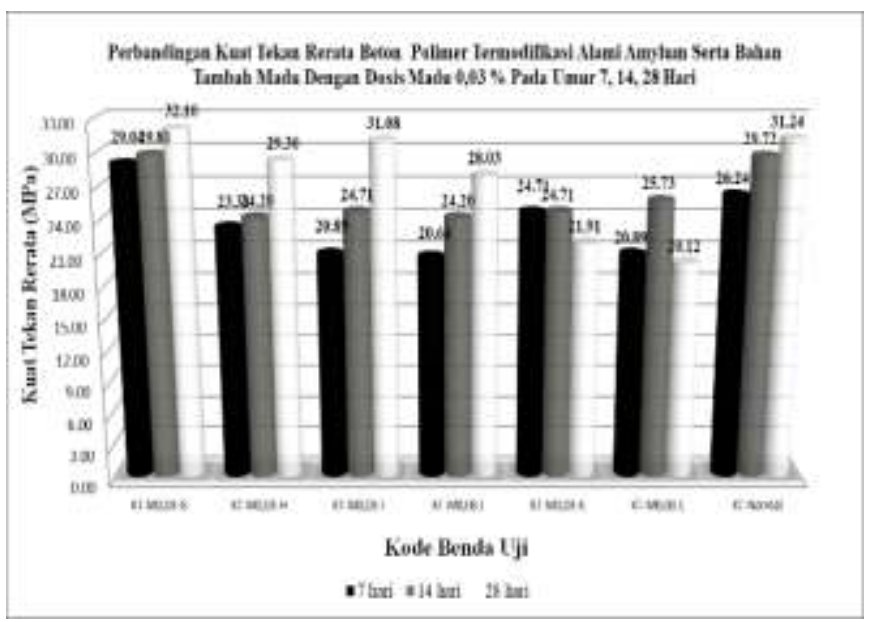

Gambar 4.6Perbandingan Kuat Tekan Rerata Beton Normal dan Beton Polimer Termodifikasi Alami Amylum serta Bahan Tambah Madu dengan dosis Madu 0,03\% pada Umur 7, 14, dan 28 Hari

Dari gambar 4.6, dapat diketahui bahwa hasil dari pengujian kuat tekan beton polimer termodifikasi alami amylum serta bahan tambah madu paling optimum terdapat pada benda uji dengan kode KTM0,03-G. Kode uji KT-M0,03-G memiliki grafik kenaikan yang stabil. Kode uji KTM0,03-G memiliki nilai kuat tekan yang lebih tinggi dari nilai kuat tekan yang direncanakan. 
4.3.7 Perbandingan Kuat Tekan Rerata

Beton Polimer Termodifikasi Alami Amylum Serta Bahan Tambah Madu Dengan Dosis Madu 0,3\% Pada Umur 7, 14, 28 Hari

Berikut perbandingan kuat tekan beton normal dan beton yang telah termodifikasi madu $0,03 \%$ pada umur $7,14,28$ hari:

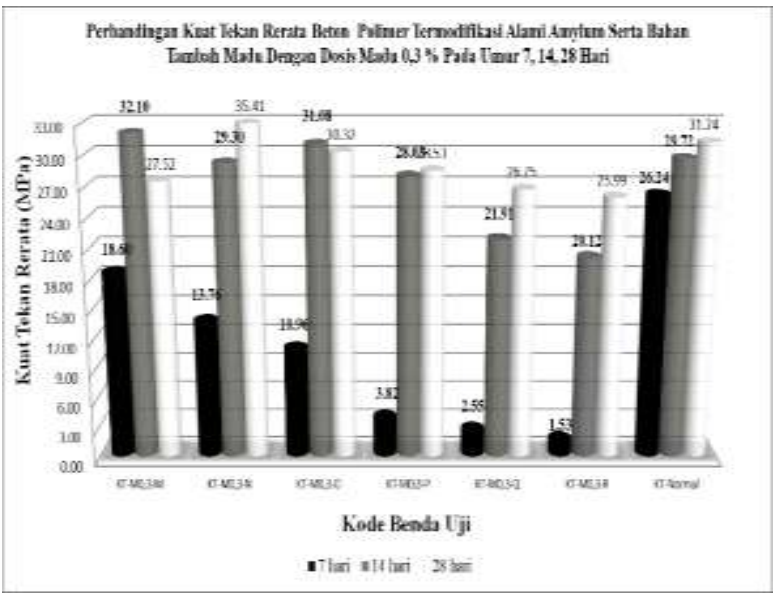

Gambar 4.7Perbandingan Kuat Tekan Rerata Beton Normal dan Beton Polimer Termodifikasi Alami Amylum serta Bahan Tambah Madu dengan dosis Madu 0,3\% pada Umur 7, 14, dan 28 Hari

Dari gambar 4.7, dapat diketahui bahwa hasil dari pengujian kuat tekan beton polimer termodifikasi alami amylum serta bahan tambah madu paling optimum terdapat pada benda uji dengan kode KTM0,3-N. Kode uji KT-M0,3-N memiliki grafik kenaikan yang stabil. Kode uji KTM0,3-N memiliki nilai kuat tekan yang lebih tinggi dari nilai kuat tekan yang direncanakan. Kode uji KT-M0,3-N juga memiliki nilai ekonomis yang lebih tinggi dikarenakan bahan yang digunakan lebih sedikit dibanding kode uji lainnya.

\subsubsection{Perbandingan Kuat Tekan Beton Polimer Termodifikasi Alami Amylum Serta Bahan Tambah Madu Umur 28 hari}

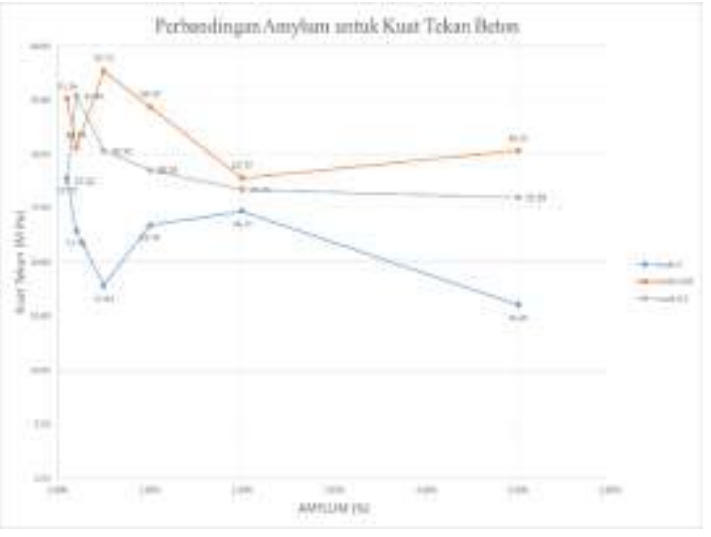

Gambar 4.8Perbandingan Amylum Kuat Tekan Beton Polimer Termodifikasi Alami Amylum serta Bahan Tambah Madu pada Umur 28 Hari

Dari pengujian kuat tekan beton yang telah dilakukan, nilai kuat tekan berdasarkan hasil pengujian kuat tekan beton tertinggi pada komposisi madu 0,03 $\%$ dengan amylum dibawah $1 \%$ yaitusebesar $37,71 \mathrm{MPa}$, tetapi kuat tekan beton optimum terdapat pada madu $0,03 \%$ juga tetapi dengan komposisiamylum dibawah $1 \%$ akan tetapi komposisinya lebih kecil dari kuat tekan tekan beton beton tertinggi, sehingga komposisi ini efisien dan ekonomis.

\section{KESIMPULAN DAN SARAN 5.1 KESIMPULAN}

1. Hasil uji kuat tekan beton tertinggi pada umur 7 hari adalah benda uji dengan komposisi madu $0,03 \%$ dan amylum 0,1 \%, yaitu sebesar 29,04 $\mathrm{MPa}$, untuk hasil uji kuat tekan beton terendah adalah benda uji dengan dengan komposisi madu 0,3\% dan amylum $5 \%$, yaitu sebesar 1,53 MPa,

2. Hasil uji kuat tekan beton tertinggi pada umur 14 hari adalah benda uji dengan komposisi madu $0 \%$ dan amylum $0,2 \%$, yaitu sebesar 31,34 
$\mathrm{MPa}$, untuk hasil uji kuat tekan beton terendah adalah benda uji dengan dengan komposisi madu $0,3 \%$ dan amylum $5 \%$, yaitu sebesar 20,13 $\mathrm{MPa}$,

3. Hasil uji kuat tekan beton tertinggi pada umur 28 hari adalah benda uji dengan komposisi madu 0,03\% dan amylum $0,5 \%$, yaitu sebesar 37,71 $\mathrm{MPa}$, untuk hasil uji kuat tekan beton terendah adalah benda uji dengan kode dengan komposisi madu $0 \%$ dan amylum $5 \%$, yaitu sebesar 16,05 $\mathrm{MPa}$,

4. Pada pengujian kuat tekan beton, hasil optimum yang didapat adalah benda uji KT-M0,03-G dengan komposisi bahan tambah madu sebesar $0,03 \%$ dan amylum sebesar $0,5 \%$ dari berat semen, karena gradasi kuat tekan pada umur beton 7, 14, dan 28 hari terus mengalami peningkatan, memiliki kuat tekan tinggi dengan mempertimbangkan komposisi yang efisien dan ekonomis,

5. Hasil uji kuat tarik belah tertinggi didapat dari benda uji dengan komposisi madu $0 \%$ dan amylum 0 $\%$, yaitu sebesar 3,88 MPa sedangkan hasil uji kuat tarik terendah didapat dari benda uji dengan komposisi madu $0,3 \%$ dan amylum $5 \%$, yaitu sebesar $2,58 \mathrm{MPa}$,

6. Pada pengujian kuat tarik belah beton, didapat hasil optimum yaitu sebesar 3,88 $\mathrm{MPa}$ pada benda uji KTB-M0-A dengan komposisi madu $0 \%$ dan amylum $0,10 \%$ dari berat semen,

7. Persentase kenaikan kuat tarik benda uji KTB-M0-A terhadap benda uji kuat tarik belah normal sebesar $1,07 \%$.

8. Perbandingan antara kuat tekan dan kuat tarik belah memiliki nilai yang presentase gradasi kenaikan yang bagus dan benda uji dengan komposisi madu 0,03\% dan amylum $0,1 \%$, yaitu sebesar $9,9 \%$.

\subsection{SARAN}

1. Penggunaan bahan tambah madu dan amylum untuk beton dalam penelitian ini dapat dikembangkan dan menjadi refrensi bagi penelitian selanjutnya,

2. Perlu diadakan penelitian lanjutan pada campuran kuat tekan beton dengan komposisi madu 0,03\% dan amylum $0,5 \%$,

3. Perlu diadakan penelitian lanjutan menggunakan madu dengan komposisi dan kandungan madu merek lain.

\section{DAFTAR PUSTAKA}

ASTM. 1995. Concrete and Agregates, Annual Book Of ASTM Standard, Vol. 04.02. Philadelphia: ASTM.

ASTM C39, Standar Metode Tes untuk Kuat Tekan Silinder Uji Beton. Annual Books of ASTM Standards.

ASTM C150. Spesifikasi Standar untuk Semen Portland. Annual Books of ASTM Standards.

Chasanah, N. 2001. Kadar Dekstrosa, Levulosa, Maltosa, serta Fruktosa Madu Segar dan Madu Bubuk dengan Bahan Pengisi Campuran Gum Arab dan Dekstin. Skripsi. Bogor: Fakultas Peternakan Institut Pertanian Bogor

Claus, E.P., Varro E., Tyler., Lynn R. B., 1970. Pharmacognosy, Lea \& Febiger, Philadelphia: 247.

Badan Standarisasi Nasional (BSN). 1994. Madu (SNI 01-3545-1994), Jakarta. 2002. Metode Pengujian Kuat Tarik Belah Beton (SNI 03-24912002), Jakarta.

-. 2004. Semen Portland (SNI 152049-2004). Jakarta. 
2011. Cara Uji Kuat Tekan Beton dengan Benda Uji Silinder yang Dicetak (SNI 1974:2011), Jakarta.

Dipohusodo, I. 1996.Manajemen Proyek dan Konstruksi. Yogyakarta.

Gregor, M., 1997. Reinforced Concrete Mechanics and Design. $3^{\text {rd }}$.

Haryanto, A.T., \& Pangestu, F. 2015. Optimasi Campuran Mortar dan Beton dengan Polimer Alami Gracilaria Sp. dan Bahan Tambah Madu. Tugas Akhir. Semarang: Fakultas Teknik Unika Soegijapranata.

Haach, et al. 2013. Development of a New Test For Determination of Tensile Strength of Concrete Blocks. Vancouver.

Hapsari, G. \& Wahyu, R. 2013. Pengaruh Penggunaan Serbuk Agar-agar (Gracilaria sp.) terhadap Kuat Tekan dan Kuat Tarik Belah Mortar Polimer. Tugas Akhir. Semarang: Fakultas Teknik Unika Soegijapranata.

Susilorini, Rr. M. I. R. 2007. Model Masalah Cabut-Serat Nylon 600 Tertanam dalam Matriks Sementitis yang Mengalami Fraktur. Disertasi. Bandung: Universitas Katolik Parahyangan.

Susilorini, Rr. M. I. R. \& Suwarno, D. 2009. Mengenal dan Memahami Teknologi Beton. Semarang: Laboratorium Bahan Bangunan Fakultas Teknik Universitas Katolik Soegijapranata.

Susilorini, Rr. M. I. R. 2012. Beton Bajik Untuk Dunia Berkelanjutan. Semarang: Penerbit Surya Perdana Semesta (SPS).

Susilorini, Rr. M. I. R., Hardjasaputra, H., Tudjono, S. 2014. Inovasi Beton Bajik untuk Beton Berkelanjutan. Laporan Akhir. Hibah Kompetensi Tahun Pertama, Ditlitabmas, Ditjen Dikti.
Susilorini, Rr. M.I. R, Suwarno, DJ., Santosa, Budi. 2017. Strategi Adaptasi Masyarakat Pesisir Semarang dan Demak untuk Mitigasi Pengurangan Resiko Bencana Banjir dan Rob Akibat Perubahan Iklim, Semarang, Laporan Akhir, INSINAS RPI, Tahun Pertama, DPTI, Kemenristekdikti.

Tjokrodimuljo, K. 1996. Teknologi Beton. Yogyakarta: Nafiri.

Wulandari, A. 2008. Studi Perilaku Kuat Tekan Dan Kuat Tarik Belah Pada Beton Dengan Menggunakan Agregat Daur Ulang. Skripsi. Jakarta: Fakultas Teknik Sipil Universitas Indonesia. 